\section{RADIO RESEARCH IN BRITAIN}

AEPORT from the Research Committee of the A Institution of Electrical Engineers under the title "British Research in the Radio Field" has been published recently by the Institution*.

While the report includes a general review of the existing facilities for radio research in Great Britain and makes some assessment of the scale of effort involved, it is primarily directed towards considering the means whereby research may be still more actively and effectively pursued and better co-ordinated. The view is expressed that the present volume of radio research is inadequate to maintain, in the face of intensified international comp tition, a progressive and flourishing radio industry.

Recognizing the difficulty, when describing research in relation to industry, of differentiating sharply between research and development, the report gives a broad general classification under the three headings : (1) basic or fundamental research ; (2) applied research or advanced development ; (3) development and design.

Attention has been concentrated, in the main, on work considered to fall in the first and second categories; but the vital importance to industry of first-class engineering development is also emphasized.

In analysing the distribution of research activity, sub-division is again made under three headings, namely: (a) academic research; (b) research by Government establishments, Department of Scientific and Industrial Research and B.B.C.; (c) industrial research.

An interesting comparison is made, in tabular form, of the distribution of the existing capacity and facilities devoted, in these spheres, to various main branches of radio research.

The conclusions and recommendations of the report are the consequences, direct and indirect, of the acceptance as a basic principle that "successful research is more dependent on the qualities, character and inspiration of the research team leaders than on any other factor governing its conduct".

In a paragraph entitled "Research Leaders", it is asserted that "The key to the expansion of research in the radio field, as in all others, lies in the discovery and encouragement of the limited group of men who are competent to act as team leaders and who possess the intellectual and personal qualities which have always proved essential for the successful pioneering of research".

The position of the universities in relation to what may be termed research potential is considered to be a central one on the ground that, not only do the universities, and to a lesser extent the technical colleges, make a very material direct contribution of original research, but also it is through their teaching activities, both undergraduate and postgraduate, that the supply of potential research workers is maintained. Fairly detailed consideration is given to the factors governing the effective pursuit of research and postgraduate study in the universities of Britain, and it is suggested that many of the considerations affecting academic research apply with equal force in relation to industrial research.

In regard to finance, the existing mechanism, whereby official support comes through the University

* British Research in the Radio Field : a Report from the Research Committee of the Institution. Pp. 20. (London: Institution of Electrical Engineers, 1947.) 18. Also J. Inst. Elect. Eng., 94, Pt. 1, 502 (Nov. 1947).
Grants Committee and through the Department of Scientific and Industrial Research, is regarded as satisfactory; but it is emphasized that an expanded postgraduate programme necessitates increased funds from these sources. It is, however, reiterated that an essential requirement in university research is freedom of action in the development of the research programme.

In relation to the staffing of university research projects, attention is directed to the importance of maintaining, through the work of permanent members of the staff, continuity and integration of effort among postgraduate student members of research teams; and, in a similar connexion, to the necessity for attracting and retaining in university laboratories adequate numbers of well-qualified laboratory assistants, technicians and craftsmen.

The postgraduate university research worker may vary in age and qualification from the relatively senior holder of a major research fellowship or scholarship to the young graduate of a few months standing. Improved financial provision is regarded as necessary for the important group that returns to the university after two or three years in industry With regard to the young graduate class, it is recom mended that a period of at least six months be spent in industry before taking up academic research.

A considerable part of the report is devoted to the question of the co-ordination of research in the radio field. A primary aim must be the early dissemination of results as widely as possible. Suggestions are made for the improvement of the existing mechanism by the use of an organisation resembling the Central Radio Bureau to collect and circulate information on researches in progress, thereby minimizing the delay which inevitably exists in the publication of completed research through the normal channels. In the field of basic research in the universities, it is considered that co-ordination of effort to a desirable degree can be better achieved by the efficient exchange of current information than by positive co-ordinative action which might take on a restrictive character.

With reference to research in Government establishments, the report welcomes the recent setting up under the rgis of the Department of Scientific and Industrial Research of a Committee on Fundamental Research in Telecommunications, and suggests that a broadening of the terms of reference of this Com. mittee and its establishment on a permanent basis would serve to co-ordinate effectively the main body of research in this sphere. It is further suggested that an effort should be made to maintain something of the co-operation obtained during the War by the Inter-Services Radio Components Research and Development Committee which operated under the Ministry of Supply.

An important example of large-scale technical co-ordination in the telecommunications field is the work of the British Telephone Technical Develop. ment Committee, which, under the chairmanship of an assistant engineer-in-chief of the Post Office, achieves the co-operation of the main telephone manufacturing companies in Britain in technical development so that individual research effort is fostered, but also, by the pooling of inventions, a unified development policy for the telecommunica. tions system as a whole is ensured.

Probably the statement of the greatest practica] significance, not only in the field of radio communi cations but also in other subjects, which the document 
contains is the following: "The Panel have been impressed by the opinion consistently advanced by the University representatives who have attended the meetings that among their graduates those suited to a research career form but a small proportion of the whole; the remainder, while fully competent to absorb and profit by the scientific and technical curriculum, appear to lack those powers of patient and deep-seated inquiry which characterize the natural research worker and lead him to expose new truths".

Such a conclusion emphasizes the duty of all in industry, research establishments or universities who have the opportunity of discovering real research ability to be vigilant for its occurrence and assiduous in its nurture.

J. Grurig

\section{THE BRITISH COUNCIL ANNUAL REPORT}

$\mathrm{T}$ HE annual report of the British Council for the year ended March 31, 1947, only became available a short time ago. The report itself is preceded by an introductory re-statement of the general aims, duties and organisation of the Council, which indicates concisely but lucidly the place of the Council in explaining British cultural achievements and the background of social life, and also the broad grounds on which a grant-in-aid of about three million pounds a year is justified. Referring to the widespread demand for teaching the English language created by the War, the report records the Council's decision in principle not to engage in the direct teaching of elementary English, but to assist, in conjunction with the ministry of education of the country concerned, in improving the standard of teaching of the English language. Concluding that too much effort had in the past been concentrated on the intelligentsia and on the capital cities of foreign countries, the Council also made every effort during the year to widen its influence through contacts with workers' educational movements and with study groups in smaller towns, and it is planned to provide a number of short-term bursaries to enable trade unionists, artisans and apprentices to visit Great Britain to meet their fellows and study the conditions of work in factories, etc. At the invitation of the Commonwealth authorities, a centre was established in Australia during the year, an experiment which has been an unqualified success.

During the year, 248 new scholarships, including three senior fellowships, were awarded as compared with 307 in 1945-46, and 190 scholarships were extended. In addition, nearly two hundred private students were assisted by the Council to secure places at British universities; and vacation courses for overseas students were held at St. Andrews, Oxford and Queen Mary College, London, the last being a specialized course on high-voltage engineering. Lecture tours organised numbered 97 in 28 countries, as against 70 in 1945-46. Thirty-seven new brochures, revised editions and reprints were issued during the year, the series generally in most demand in Europe being British Life and Thought, Science in Britain and The Arts in Britain; in the Balkans, the Middle East, Africa and South America, Britain Advances and British People are more in demand. The Council's work in the field of copyright has now been transferred to the Central Office of Information, but the year was marked by the founding of Council libraries in many European countries and their consolidation in others. Collaboration with the Information Services of the Foreign Office towards pooling resources in joint libraries, functioning both as special reference centres on current British affairs and as Council libraries, is designed to prevent overlapping. Large exchanges of books took place with the U.S.S.R. through the Lenin Library at Moscow, and universities and other centres of Russian studies in Britain have thus received valuable material. In the Colonies, the Council is concerned mainly with assisting the development of library services generally. Two small exhibitions of scientific and medical books were sent to Norway, and an exhibition, with extensive technical and medical sections, toured widely in Switzerland, while one of scientific and technical books was shown in Brussels, Antwerp, Liège, Ghent and Louvain. Some 1,800 periodicals, covering all branches of the humanities, science, medicine and technology, were made available in 1,168 centres in eighty-five countries, and exchanges totalled 3,476 , involving 791 foreign and 765 British periodicals, including 77 British Commonwealth publications. Indexes and contents lists for the war years of sixty specialist periodicals were microfilmed and 25 copies of the film distributed to Austria, Belgium, China, Czechoslovakia, Denmark, Finland, France, Greece, Netherlands, Hungary, Italy, Norway, Poland and Yugoslavia, while in Europe 67 universities and specialist libraries in 15 countries were supplied with British periodicals by presentation or exchange.

Scientific workers form a large proportion of British Council visitors to Great Britain and of lect. urers sponsored overseas by the Council. In collabora. tion with the Scientific Instrument Manufacturers' Association, under the auspices of the Academy of Engineering Science and the Swedish Association of Technical Physics, an exhibition of scientific instruments was organised in Stockholm in May-June, 1946. Assistance was given to the expedition planning to survey a large freshwater lake in Venezuela, and arrangements have been made for the exchange of biological specimens between Brazil and various museums and laboratories in Britain. Many countries have used the Science Department for effecting ex. changes of material, and the Department has advised on scientific appointments overseas, scientific films and film strips and on the publication of Science in Britain. Production of Science Comment was suspended in September 1946 as it had become partly absorbed in the modified Monthly Science News.

The fourth volume of British Medical Bulletin, produced during the year in Spanish and French editions as well, has been placed on a sales basis in countries where currency and other regulations permit, and free distribution is being reduced to a minimum. Medical periodicals received by the Library from other countries, mainly in exchange for the British Medical Bulletin, now number more than 650, and all important British medical books as well as many foreign ones are now received for review in the Bulletin. The Medical Department also handled an increasing number of inquiries, mainly bibliographical, and supplied many reprints and Photostat copies of articles in response to requests from abroad. Advice was given on questions of technical education and postgraduate training in Britain to 93 overseas studies from thirty countries, ranging over some twenty branches of engineering and science, and advice was also given on numerous agricultural subjects 